\title{
Usefulness of Measuring Serum LH Concentration on Day 1 Before Ovarian Stimulation in Non- Obese Polycystic Cases
}

\section{Original Article}

\author{
Eman Ali Abd El Fattah
}

Shatby Maternity Hospital, Department of Obstetrics and Gynecology, Faculty of Medicine, Alexandria University, Alexandria, Egypt.

\begin{abstract}
Background: Polycystic ovarian syndrome is associated with high LH related to infertility.

Objectives: We aim at detecting the effect of day $1 \mathrm{LH}$ on the outcome of controlled ovarian stimulationin slim PCOS cases to determine a cut- off value for LH.

Study design: We retrospectively analysed the out- come of stimulated cycles in PCOS cases with a body mass index 18-29 $\mathrm{kg} / \mathrm{m} 2$ visiting the reproductive medicine clinic in El Shatby university hospital ,Egypt. They were divided into two groups: Group A( LH less than or equal to 6IU/dl ) and Group B ( LH more than 6). Recombinent FEH was started day 2 and ovarian responce was monitored by folllicular scanning and serum estradiol (E2). HCG trigger was considered when the leading follicle is at least $18 \mathrm{~mm}$, luteal phase was supported by vaginal micronised progesterone. Prenancy test in blood was done 16 days later.

Results: significant difference was found in gonadotrophin dose and in pregnancy rate.

Conclusion: Day $1 \mathrm{LH}$ had a negative predictive value better than a positive predictive value for occurrence of pregnancy.
\end{abstract}

Submitted: 21 October 2016, Accepted: 1 February 2017.

Key Words: LH, PCOS, Ovulation, Pregnancy.

Corresponding Author: Eman Ali Abd El Fattah, Department of Obstetrics and Gynecology, Faculty of Medicine, Alexandria University, Alexandria, Egypt., E-mail: eman0eman0eman7@gmail.com

ISSN: 2090-7265, February 2017, Vol. 7, No. 1

\section{INTRODUCTION}

TSteroidogenesis and folliculogenesis are regulated by Luteinizing hormone, Follicle stimulating hormone and GnRH. LH plays a role in both oocyte maturation and ovulation through a mechanism which is poorly understood(1).Granulosa cells acquire LH receptors by the mid follicular phase of the menstrual cycle coinciding with a rise in LH level (2) and a premature LH surge may cause early luteinization and follicular atresia in cases of controlled ovarian stimulation (3) . High LH levels causes premature secretory transformation of the endometrium decreasing the chances of implantation and thereby decreasing pregnancy rates ${ }^{4-6}$.

\section{PATIENTS AND METHODS}

We retrospectively analysed the outcome of controlled ovarian stimulation performed in the period between January 2015 and January 2016. A total of 122 women with polycystic ovaries were recruited at the clinic of Reproductive Medicine, Department of Obstetrics and Gynecology, Faculty of Medicine, Alexandria University, Egypt.
This diagnostic test accuracy (DTA) research planned to determine a cut-off value for LH in slim females with polycystic ovaries anticipating pregnancy in day 1 prior to ovarian stimulation.

Inclusion criteria: Women with polycystic ovaries, Body Mass Index (BMI) ranging between 18 and $29 \mathrm{~kg} /$ $\mathrm{m}^{2}$, day $1 \mathrm{AMH}$ level above $1.5 \mathrm{ng} / \mathrm{mL}$, FSH level less than $10 \mathrm{IU} / \mathrm{mL}$, prolactin level $<25 \mathrm{ng} / \mathrm{mL}$, normal TSH 0.4 to $4.0(\mathrm{mIU} / \mathrm{L})$., $\mathrm{T} 3$ from 3 to $11 \mathrm{mcg} / \mathrm{dL}$, T4 levels from 4.5 to $11.2 \mathrm{mcg} / \mathrm{dl}$ and normal semen analysis for the male.

Exclusion criteria: Endometriosis or uterine abnormalities in ultrasound, and history of previous adnexal surgery, They were retrospectively divided into two groups according to serum $\mathrm{LH}$ on day 1 prior to ovarian stimulation:

Group-A included women with LH less than or equal to 6

Group-B included women whose LH is more than 6

Data recorded for the analysis included age, gravidity and parity, days of stimulation, doses of gonadotrophins , 
estradiol level on the day of human chorionic gonadotropin (hCG) administration, endometrial thickness, number of stimulated cycles and pregnancy outcome.

The recombinant FSH (rFSH) (Gonapure, Menapharm,orPuregon, Organon) was started at a dose of 75- 225 IU subcutaneously per day on day 2 of the cycle (which is considered as Day 1 of stimulation) according to number of the antral follicles, baseline FSH and age of patient. The ovarian response and the need for further doses were monitored by ultrasound and Estradiol (E2) on day 5 of the stimulation.

Day of hCG trigger was considered when the leading follicle was $>18 \mathrm{~mm}$ on follicular imaging, patients received injectable- hCG (13000 IU SC; Ovitrelle, Serono S.A. 10,000 IU IM; Choriomon, Organon).

The luteal phase was supported by daily vaginal administration of $200 \mathrm{mg}$ micronized Progesterone (Prontogest 200, Bayer) beginning 48 hours after hCG injection. Serum concentration of b-hCG was measured on day 16 after day of hCG trigger, and in case of concentrations $20 \mathrm{IU} / 1$, which indicated conception, ultrasound scans were performed at 7-8 weeks gestation to verify the viability of pregnancy.

The specific aims are to assess the impact of day 1 serum LH concentration on ovarian response and pregnancy outcome.

\section{RESULTS}

The original number of cases fulfilling the inclusion criteria was 122 but 4 cases did not continue the stimulation protocol so they were excluded from the study. A total of 118 cases were divide into two groups according to $\mathrm{LH}$ level on day 1 prior to stimulation

The two groups are Group-A, which included women with LH less than or equal to 6 and group-B including women with LH more than ${ }^{6}$.

Age, gravidity and parity were not significantly different between both groups shown in Table 1 and Figure. 1, the mean for age in group A was 27.34 compared to 25.95 in group B. We used Levene's test for equality of variances and independent samples t-test for evaluating age. The $\mathrm{P}$ values proved to be non-significant as they were 0.565 and 0.070 , respectively.. MannWhitney $U$ test used for evaluating gravidity and parity proved also to be non-significant ( $p=0.711$ for gravidity and $p=0.559$ for parity). Duration of stimulation was not significant between the two groups $(p=0.952)$. Ovarian stimulation in group A had a mean of 12.28 compared to 12.32 in group-B (Table 2 and Figure 2). Significant difference was found between the two groups as regards doses of gonadotrophins $(p=0.000)$ where group-A used lower doses of gonadotrophins (a mean of 177.3630) to reach a mature ovarian follicular size $\geq 18 \mathrm{~mm}$ compared to a mean of 227.9891 in group B (Table 3 (III) and Figure 3).

Estradiol levels revealed non-significant difference between the two groups $(p=0.967)$. The means were 2288.68 and 2229.54 for group- A and B, respectively (Table 4 and Figure 4).

No significant difference was found in the endometrial thickness between the two groups $(p=0.767)$. The mean for endometrial thickness in group A was 9.30 compared to 9.23 in group B (Table 5 (V) and Figure 5). A significant association between serum LH and pregnancy was found, whereas in group A, 15 out of $58(20.5 \%)$ cases got pregnant and in group B only 3 out of $43(6.5 \%)$ cases got pregnant showing a significant difference between the two groups where $p=0.038 *$ ) Table 6) and Figure 6).

The value of serum LH concentration on day 1 prior to ovarian stimulation discriminating conception versus non-conception cycles was examined with ROC analysis.

\section{ROC curve}

Area under the curve $=0.764,95 \%$ confidence interval $b$ of 0.677 to 0.837 ( $Z=4.476, p=0.0001$.) We used Youden methodology to adapt a cut off value of LH. Youden index suggests a value of $\mathrm{LH} \leq 3.9$ IU for achievement of pregnancy with sensitivity of $77.78,95 \%$ confidence interval $b$ of 0.677 to 0.837 ), (specificity of $72.28,95 \%$ confidence interval $b$ of 0.677 to 0.837 ) (positive predictive value of 33.3, confidence interval b of 19.6- 49.5) and (negative predictive of 94.8 , confidence interval b of 87.2-98.6). 


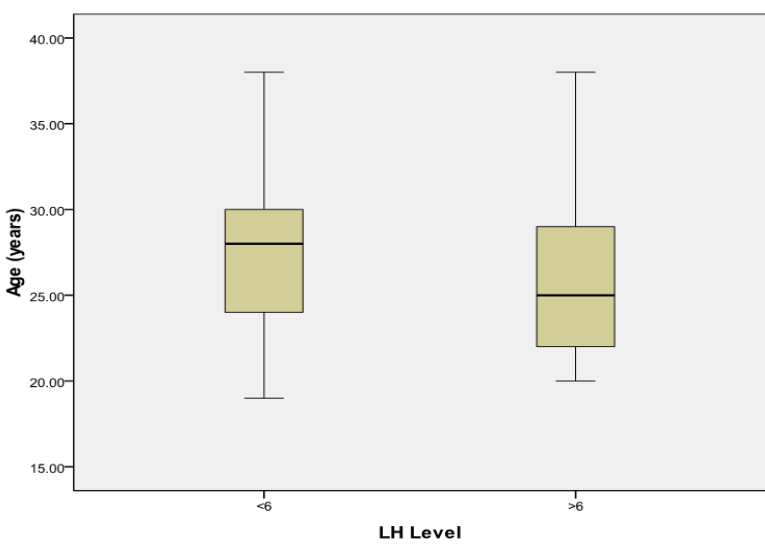

Figure 1: Box and whisker graph of age (years), the thick line in the middle of the box represents the median, the box represents the inter-quartile range (from $25^{\text {th }}$ to $75^{\text {th }}$ percentiles), the whiskers represents the minimum and maximum values.

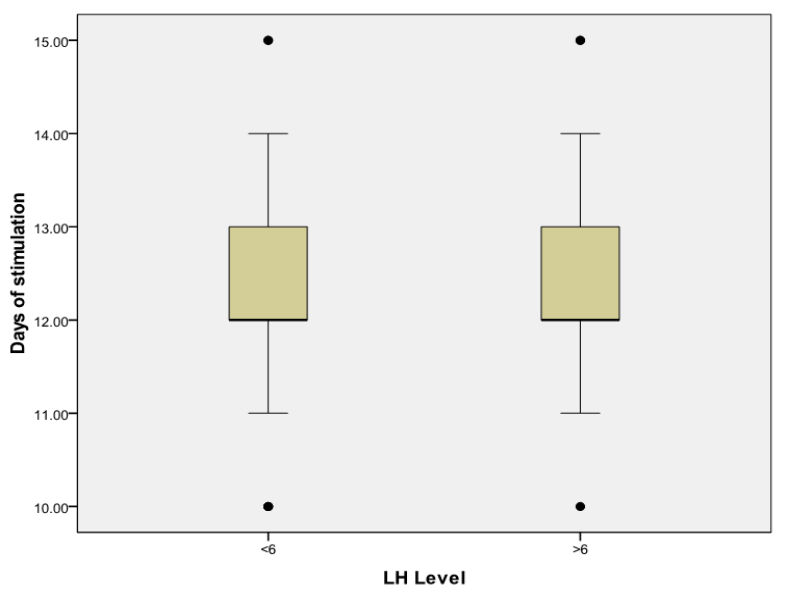

Figure 2: Box and whisker graph of days of stimulation, the thick line in the middle of the box represents the median, the box represents the inter-quartile range (from $25^{\text {th }}$ to $75^{\text {th }}$ percentiles), the whiskers represents the minimum and maximum values after excluding outliers (black-filled circles).

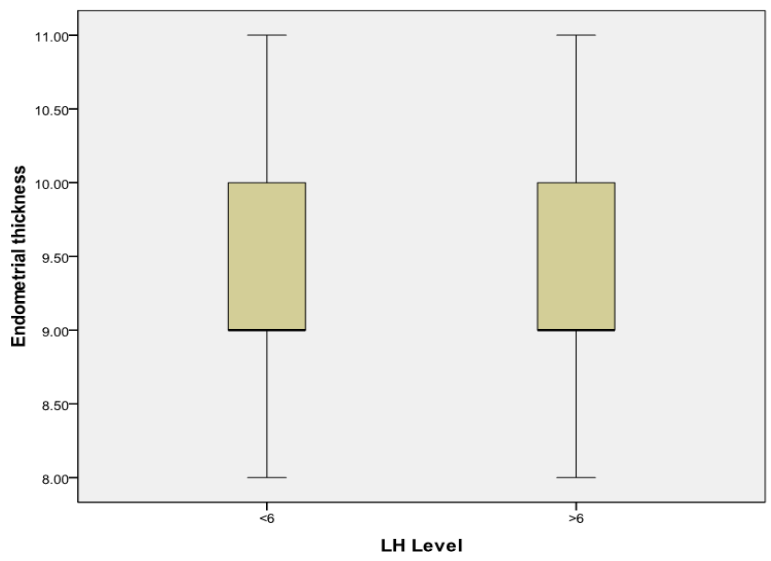

Figure 5: Box and whisker graph of endometrial thickness on the day of hCG, the thick line in the middle of the box represents the median, the box represents the inter-quartile range (from $25^{\text {th }}$ to $75^{\text {th }}$ percentiles), the whiskers represents the minimum and maximum values.

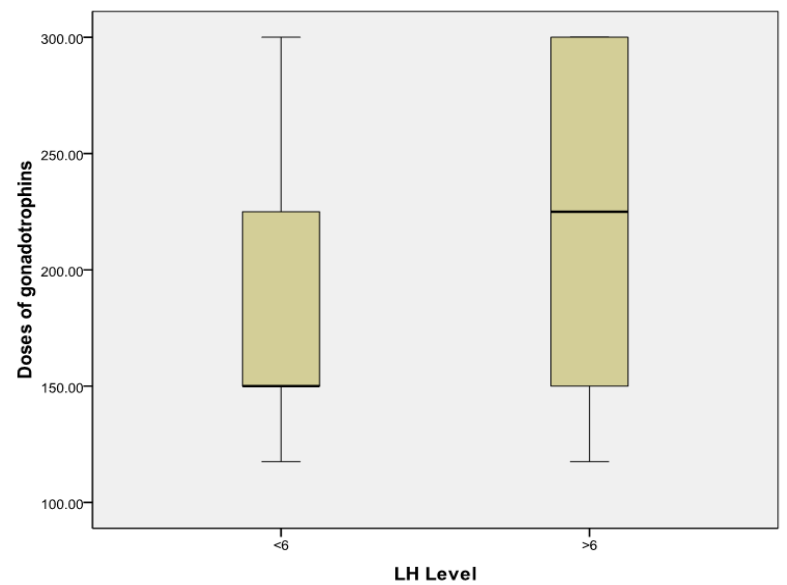

Figure 3: Box and whisker graph of doses of gonadotrophins, the thick line in the middle of the box represents the median, the box represents the inter-quartile range (from $25^{\text {th }}$ to $75^{\text {th }}$ percentiles), the whiskers represents the minimum and maximum values.

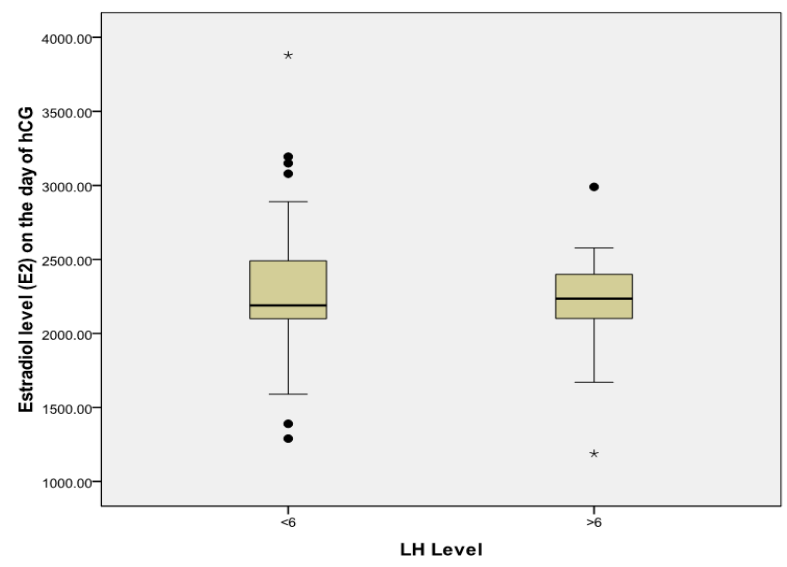

Figure 4: Box and whisker graph of estradiol level (E2) on the day of hCG, the thick line in the middle of the box represents the median, the box represents the inter-quartile range (from $25^{\text {th }}$ to $75^{\text {th }}$ percentiles), the whiskers represents the minimum and maximum values after excluding outliers (black-filled circles) and extremes (black asterisks).

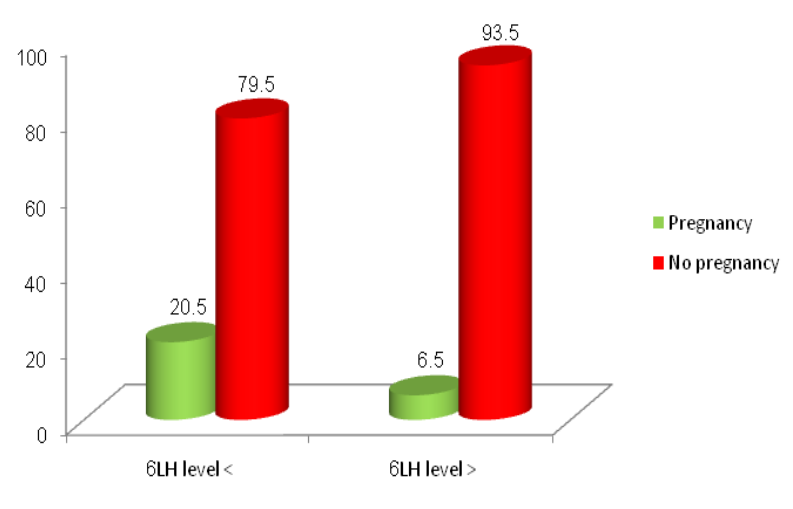

Figure 6: LH level and occurrence of pregnancy. 


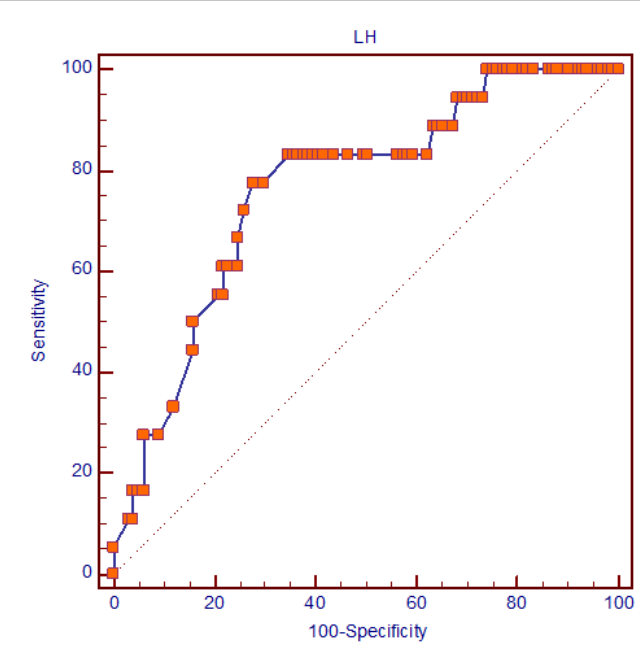

Figure 7: sensitivity and specificity of LH for achievement of pregancy.

Table 1: Comparison of age, parity and gravidity

\begin{tabular}{|c|c|c|c|}
\hline & $\begin{array}{c}\text { LH level }<6 \\
(n=73)\end{array}$ & $\begin{array}{c}\text { LH level }>6 \\
(n=46)\end{array}$ & $\begin{array}{c}\text { Total } \\
(n=119)\end{array}$ \\
\hline \multicolumn{4}{|l|}{ Age (years) } \\
\hline KS test $\mathrm{D}$ & $\begin{array}{c}0.081(p=0.200 \\
\text { NS })\end{array}$ & $\begin{array}{c}0.126(p=0.063 \\
\text { NS })\end{array}$ & $\begin{array}{c}0.091 \\
\left(p=0.017^{*}\right)\end{array}$ \\
\hline Minimum & 19.00 & 20.00 & 19.00 \\
\hline Maximum & 38.00 & 38.00 & 38.00 \\
\hline Mean & 27.34 & 25.95 & 26.80 \\
\hline$\pm \mathrm{SD}$ & 3.848 & 4.304 & 4.069 \\
\hline Median & 28.00 & 25.00 & 26.00 \\
\hline $\begin{array}{l}\text { Inter-quartile } \\
\text { range }\end{array}$ & $24.00-30.00$ & $22.00-29.00$ & $24.00-29.00$ \\
\hline $\begin{array}{l}\text { Levene's Test } \\
\text { for Equality } \\
\text { of Variances }\end{array}$ & \multicolumn{2}{|c|}{$\begin{array}{c}\mathrm{F}=0.333 \\
p=0.565 \mathrm{NS}\end{array}$} & \\
\hline $\begin{array}{l}\text { Independent } \\
\text { Samples t-test }\end{array}$ & \multicolumn{2}{|c|}{$\begin{array}{c}\mathrm{t}=1.827 \\
p=0.070 \mathrm{NS}\end{array}$} & \\
\hline \multicolumn{4}{|l|}{ Gravidity } \\
\hline Minimum & 0.00 & 0.00 & 0.00 \\
\hline Maximum & 3.00 & 3.00 & 3.00 \\
\hline Median & 1.00 & 0.50 & 1.00 \\
\hline $\begin{array}{l}\text { Inter-quartile } \\
\text { range }\end{array}$ & $0.00-1.00$ & $0.00-2.00$ & $0.00-1.00$ \\
\hline $\begin{array}{l}\text { Mann- } \\
\text { Whitney } \\
\text { U test }\end{array}$ & \multicolumn{2}{|c|}{$\begin{array}{c}\mathrm{Z}=0.371 \\
\mathrm{p}=0.711 \mathrm{NS}\end{array}$} & \\
\hline \multicolumn{4}{|l|}{ Parity } \\
\hline Minimum & 0.00 & 0.00 & 0.00 \\
\hline Maximum & 2.00 & 3.00 & 3.00 \\
\hline Median & 0.00 & 0.00 & 0.00 \\
\hline $\begin{array}{l}\text { Inter-quartile } \\
\text { range }\end{array}$ & $0.00-1.00$ & $0.00-1.00$ & $0.00-1.00$ \\
\hline $\begin{array}{l}\text { Mann-Whitney } \\
\text { U test }\end{array}$ & \multicolumn{2}{|c|}{$\begin{array}{c}\mathrm{Z}=0.584 \\
\mathrm{p}=0.559 \mathrm{NS}\end{array}$} & \\
\hline
\end{tabular}

KS: Kolmogorov-Smirnov test of normality
Table 2: Days of stimulation.

\begin{tabular}{|c|c|c|c|}
\hline & $\begin{array}{c}\text { LH level }<6 \\
(n=73)\end{array}$ & $\begin{array}{c}\begin{array}{c}\text { LH level }>6 \\
(n=46)\end{array}\end{array}$ & $\begin{array}{c}\text { Total } \\
(\mathrm{n}=119)\end{array}$ \\
\hline \multicolumn{4}{|l|}{$\begin{array}{l}\text { Days of } \\
\text { stimulation }\end{array}$} \\
\hline KS test D & $\begin{array}{c}0.176 \\
(p=0.000 *)\end{array}$ & $\begin{array}{c}0.274 \\
(p=0.000 *)\end{array}$ & $\begin{array}{c}0.214 \\
\left(\mathrm{p}=0.000^{*}\right)\end{array}$ \\
\hline Minimum & 10.00 & 10.00 & 10.00 \\
\hline Maximum & 15.00 & 15.00 & 15.00 \\
\hline Mean & 12.28 & 12.32 & 12.30 \\
\hline$\pm \mathrm{SD}$ & 1.123 & 1.055 & 1.093 \\
\hline Median & 12.00 & 12.00 & 12.00 \\
\hline $\begin{array}{l}\text { Inter-quartile } \\
\text { range }\end{array}$ & $12.00-13.00$ & $12.00-13.00$ & $12.00-13.00$ \\
\hline $\begin{array}{l}\text { Mann-Whitney } \\
\text { U test }\end{array}$ & \multicolumn{2}{|c|}{$\begin{array}{c}\mathrm{Z}=0.060 \\
\mathrm{p}=0.952 \mathrm{NS}\end{array}$} & \\
\hline
\end{tabular}

Table 3: Doses of gonadotrophins.

\begin{tabular}{|c|c|c|c|}
\hline & $\begin{array}{c}\text { LH level <6 } \\
(n=73)\end{array}$ & $\begin{array}{c}\text { LH level }>6 \\
(n=46)\end{array}$ & $\begin{array}{c}\text { Total } \\
(n=119)\end{array}$ \\
\hline \multicolumn{4}{|l|}{$\begin{array}{l}\text { Doses of } \\
\text { gonadotrophins }\end{array}$} \\
\hline KS test D & $\begin{array}{c}0.334 \\
(p=0.000 *)\end{array}$ & $\begin{array}{c}0.261 \\
\left(\mathrm{p}=0.000^{*}\right)\end{array}$ & $\begin{array}{c}0.284 \\
(\mathrm{p}=0.000 *)\end{array}$ \\
\hline Minimum & 117.50 & 117.50 & 117.50 \\
\hline Maximum & 300.00 & 300.00 & 300.00 \\
\hline Mean & 177.3630 & 227.9891 & 196.9328 \\
\hline$\pm \mathrm{SD}$ & 59.60502 & 69.99925 & 68.18581 \\
\hline Median & 150.0000 & 225.0000 & 150.0000 \\
\hline $\begin{array}{l}\text { Inter-quartile } \\
\text { range }\end{array}$ & $150.00-225.00$ & $150.00-300.00$ & $\begin{array}{l}150.00- \\
225.00\end{array}$ \\
\hline $\begin{array}{l}\text { Mann-Whitney } \\
\text { U test }\end{array}$ & \multicolumn{2}{|c|}{$\begin{array}{c}\mathrm{Z}=3.753 \\
\mathrm{p}=0.000 * *\end{array}$} & \\
\hline
\end{tabular}

KS: Kolmogorov-Smirnov test of normality

Table 4: Estradiol level.

\begin{tabular}{|c|c|c|c|}
\hline & $\begin{array}{c}\text { LH level }<6 \\
(n=73)\end{array}$ & $\begin{array}{c}\text { LH level }>6 \\
(n=46)\end{array}$ & $\begin{array}{c}\text { Total } \\
(n=119)\end{array}$ \\
\hline \multicolumn{4}{|l|}{ Estradiol level } \\
\hline KS test D & $\begin{array}{c}0.186 \\
\left(p=0.000^{*}\right)\end{array}$ & $\begin{array}{c}0.125(p=0.071 \\
\text { NS })\end{array}$ & $\begin{array}{c}0.111 \\
(\mathrm{p}=0.001 *)\end{array}$ \\
\hline Minimum & 1290.00 & 1188.00 & 1188.00 \\
\hline Maximum & 3879.00 & 2990.00 & 3879.00 \\
\hline Mean & 2288.68 & 2229.54 & 2265.82 \\
\hline$\pm \mathrm{SD}$ & 424.594 & 277.268 & 374.374 \\
\hline Median & 2190.00 & 2235.00 & 2198.00 \\
\hline $\begin{array}{l}\text { Inter-quartile } \\
\text { range }\end{array}$ & $\begin{array}{c}2098.50- \\
2490.50\end{array}$ & $\begin{array}{c}2100.75- \\
2407.50\end{array}$ & $\begin{array}{c}2100.00- \\
2456.00\end{array}$ \\
\hline $\begin{array}{l}\text { Mann-Whitney } \\
\text { U test }\end{array}$ & \multicolumn{2}{|c|}{$\begin{array}{c}\mathrm{Z}=0.041 \\
\mathrm{p}=0.967 \mathrm{NS}\end{array}$} & \\
\hline
\end{tabular}

KS: Kolmogorov-Smirnov test of normality 
Table 5: Endometrial thickness

\begin{tabular}{lccc}
\hline & $\begin{array}{c}\text { LH level }<\mathbf{6} \\
(\mathbf{n}=\mathbf{7 3})\end{array}$ & $\begin{array}{c}\text { LH level }>\mathbf{6} \\
(\mathbf{n}=\mathbf{4 6})\end{array}$ & $\begin{array}{c}\text { Total } \\
(\mathbf{n}=\mathbf{1 1 9})\end{array}$ \\
\hline $\begin{array}{l}\text { Endometrial } \\
\text { thickness }\end{array}$ & $\begin{array}{c}0.235 \\
\left(\mathrm{p}=0.000^{*}\right)\end{array}$ & $\begin{array}{c}0.313 \\
\left(\mathrm{p}=0.000^{*}\right)\end{array}$ & $\begin{array}{c}0.264 \\
\left(\mathrm{p}=0.000^{*}\right)\end{array}$ \\
KS test D & 8.00 & 8.00 & 8.00 \\
Minimum & 11.00 & 11.00 & 11.00 \\
Maximum & 9.30 & 9.23 & 9.27 \\
Mean & 0.892 & 0.672 & 0.812 \\
\pm SD & 9.00 & 9.00 & 9.00 \\
Median & $9.00-10.00$ & $9.00-10.00$ & $9.00-10.00$ \\
$\begin{array}{l}\text { Inter-quartile } \\
\text { range }\end{array}$ & $\begin{array}{l}\mathrm{Z}=0.297 \\
\text { Mann-Whitney }\end{array}$ \\
\begin{tabular}{l} 
U test \\
\hline
\end{tabular}
\end{tabular}

KS: Kolmogorov-Smirnov test of normality

Table 6: Pregnancy

\begin{tabular}{lccc}
\hline & $\begin{array}{c}\text { LH level }<\mathbf{6} \\
(\mathbf{n}=73)\end{array}$ & $\begin{array}{c}\text { LH level }>\mathbf{6} \\
(\mathbf{n}=\mathbf{4 6})\end{array}$ & $\begin{array}{c}\text { Test of } \\
\text { significance })\end{array}$ \\
\hline Pregnancy & & & \\
-No & $58(79.5 \%)$ & $43(93.5 \%)$ & $\mathrm{X} 2=4.324$ \\
-Yes & $15(20.5 \%)$ & $3(6.5 \%)$ & $\mathrm{p}=0.038^{*}$ \\
\hline
\end{tabular}

$X 2$ : Pearson Chi-Square

Table 7: ROC curve

\begin{tabular}{|c|c|c|}
\hline Variable & LH & \\
\hline \multirow{2}{*}{ Classification variable } & Pregnancy & \\
\hline & Pregnancy & \\
\hline \multicolumn{2}{|l|}{ Sample size } & 119 \\
\hline Positive group: & Pregnancy $=1$ & 18 \\
\hline Negative group: & Pregnancy $=0$ & 101 \\
\hline Disease prevalence $(\%)$ & & 15.1 \\
\hline \multicolumn{3}{|l|}{ Area under the ROC curve (AUC) } \\
\hline Area under the ROC curve (AUC) & & 0.764 \\
\hline Standard Error ${ }^{\mathrm{a}}$ & & 0.0590 \\
\hline $95 \%$ Confidence interval $^{\mathrm{b}}$ & & 0.677 to 0.837 \\
\hline z statistic & & 4.476 \\
\hline Significance level P (Area=0.5) & & $<0.0001$ \\
\hline \multicolumn{3}{|l|}{ DeLong et al., 1988} \\
\hline \multicolumn{3}{|l|}{${ }^{\mathrm{b}}$ Binomial exact } \\
\hline \multicolumn{3}{|l|}{ Youden index } \\
\hline Youden index J & & 0.5006 \\
\hline Associated criterion & & $\leq 3.9$ \\
\hline Sensitivity & & 77.78 \\
\hline Specificity & & 72.28 \\
\hline
\end{tabular}

\section{DISCUSSION}

A great deal of discussion has been dedicated to the gonadotrophin need of the developing follicles. As described in the classic "two-cells-two-gonadotrophin" theory, LH is needed to provide the granulosa cells with androgen precursors for estradiol biosynthesis. FSH alone can induce follicle growth, but without $\mathrm{LH}$, estradiol levels remain low and pregnancy will not occur. There is no debate about the need for both hormones in women with hypogonadotropic hypogonadism, but there is significant disagreement about the need for $\mathrm{LH}$ in "endocrinologically normal" women.

Polycystic ovary syndrome (PCOS), a relatively common reproductive endocrine disorder often associated with high endogenous LH secretion, menstrual cycle disorders, infertility and high rates of spontaneous abortion, was considered the paradigm condition that proved the potential untoward actions of $\mathrm{LH}$. LHstimulated theca cell androgen secretion may be involved in the promotion of atresia of non-dominant follicles in the normal menstrual cycle.

This retrospective study revealed that the varying $\mathrm{LH}$ levels did not have an impact on the duration of ovarian stimulation or serum estradiol levels which reflect the approximate number of mature follicles, but we found that it affected conception. In a study by Bosch et $\mathrm{al}^{7}$ the author did not find any difference in the number of dominant follicles in groups having premature luteinization and the other group with no premature luteinization in patients undergoing IVF and in their study LH values in both the groups were comparable. In a study by Merviel et al.on patients undergoing IVF $^{8}$ follicles $>15 \mathrm{~mm}$ were more in the group with $\mathrm{LH}<0.5$ $\mathrm{IU} / \mathrm{L}$, also oocyte retrieval rate and the better embryos were seen in this group, however they also did not find any difference in the implantation and pregnancy rate, contrary to our study where we found a significant difference between different groups of LH as regards conception.

In a similar study by Bosch et $\mathrm{al}^{9}$ found there was no difference in the number of oocytes retrieved, fertilization rate, number of embryos transferred, implantation rate and pregnancy rate in various LH groups, but they had commented on the number of mature follicles.

Nicole et $\mathrm{al}^{10}$ in their study state that a transient elevation of $\mathrm{LH}$ in a patient undergoing IVF with a GnRH antagonist protocol does not impair clinical pregnancy rate per ET and therefore, should not be a reason to cancel a cycle.

Although LH receptors have not yet been identified in oocytes, excessive LH may disrupt granulosa cell communication in the cumulus-oophorus, which is 
critical to maintain the oocyte in the dictyate stage of meiosis until ovulation ${ }^{11,}{ }^{12}$. Thus, according to this theory, abnormal oocyte maturation could be responsible for the reduced fertility and increased miscarriage rates frequently encountered in PCOS.

Adverse outcomes from elevated serum LH levels have been observed in a variety of studies. A significant reduction in the rate of fertilization was observed in women with raised basal LH levels (greater than one standard deviation from the mean) undergoing treatment with IVF with ovarian stimulation using clomiphene citrate (CC), hMG or a combination of the two ${ }^{13}$. In another study, in women undergoing IVF treatment with a combination of $\mathrm{CC}$ and $\mathrm{hMG}$, there were no pregnancies recorded if the urinary output of LH was elevated when measured two days prior to the day of hCG administration ${ }^{14}$. In women with polycystic ovary syndrome, the effect on outcome of the high endogenous levels of LH was observed in a study using pulsatile GnRH to induce ovulation; basal LH levels were lower in women who conceived compared to those who did not, and the rate of miscarriage was higher in those who had elevated levels of LH compared to those who had ongoing pregnancies ${ }^{15}$. The effect of raised LH levels in the follicular phase of spontaneous menstrual cycles was also investigated and found to be detrimental. A higher likelihood of pregnancy was observed when the LH level was $<10$ IU/L and the miscarriage rate was significantly higher in women with $\mathrm{LH}$ levels $>10 \mathrm{IU} / \mathrm{L}^{16}$.

Our results are consistent with previous researchers, despite having low event rate yet we were able to prove our assumption/view about the value of a low level of LH prior to ovulation stimulation and suggesting a cut off level of $\mathrm{LH} \leq 3.9$ for a better conception rate.

\section{CONCLUSION}

Day 1 serum LH level proved to have a negative predictive value rather than its positive predictive value for achievement of pregnancy after ovulation stimulation in slim cases with polycystic ovarian syndrome. This may be attributed to low event rate (18/119) as the follow up after ovulation triggering and luteal phase support was not possible for all cases due to some social beliefs in our community "not all pregnant females will declare their pregnancy". So, lost cases were considered censored (not pregnant).

\section{CONFLICT OF INTEREST}

We have no conflict of interest.

\section{ACKNOWLEDGEMENTS}

Thanks to professor doctor El Sayed Amr for his assistance in statistics

\section{REFERENCES}

1. Knobil E. The neuroendocrine control of the menstrual cycle. Recent Prog Horm Res.1980; 36:53-88.

2. Hillier SG, Tetsuka M, Fraser HM. Location and developmental regulation of androgen receptor in primate ovary. Hum Reprod. 1997;12(1):107-111.

3. Diedrich K, Diedrich C, Santos E, Zoll C, al Hasani $\mathrm{S}$, Reissmann T, et al. Suppression of the endogenous luteinizing hormone surge by the gonadotropinreleasing hormone antagonist Cetrorelix during ovarian stimulation. Hum Reprod 1994;9(5):788-791.

4. Kolibianakis EM, Albano C, Kahn J, Camus M, Tournaye H, Van Steirteghem AC, et al. Exposure to high levels of luteinizing hormone and estradiol in the early follicular phase of gonadotropinreleasing hormone antagonist cycles in associated with a reduced chance of pregnancy. Fertil Steril 2003;79(4):873-880.

5. Kolibianakis E, Borgain C, Albano C, Osmanagaoglu K, Smitz J, Van Steirteghem A, et al. Effect of ovarian stimulation with recombinant follicle-stimulating hormone, gonadotropin releasing hormone antagonists, and human chorionic gonadotropin on endometrial maturation on the day of oocyte pickup. Fertil Steril 2002;78(5):1025-1029.

6. Al-Inany H, Aboulghar MA, Mansour RT, Serour GI. Optimizing GnRH antagonist administration: Metaanalysis of fixed versus flexible protocol. Reprod Biomed Online 2005;10(5):567-570.

7. Ernesto Bosch, Ivan Valencia, Ernesto Escudero, Juana Crespo, Carlos Simon, Jose Remohi, et al. Premature luteinization during gonadotropinreleasing hormone antagonist cycles and its relationship with in vitro fertilization outcome. Fertil Steril 2003;80(6):1444- 1449.

8. Merviel P, Antoine JM, Mathieu E, Millot F, Mandelbaum J, Uzan S. Luteinizing hormone concentrations after gonadotropin-releasing hormone antagonist administration do not influence pregnancy 
rates in in vitro fertilization-embryo transfer. Fertil Steril 2004;82(1):119-125.

9. Bosch E, Escudero E, Crespo J, Simón C, Remohí J, Pellicer A.. Serum luteinizing hormone in patients undergoing ovarian stimulation with gonadotropinreleasing hormone antagonists and recombinant follicle-stimulating hormone and its relationship with cycle outcome. Fertil Steril 2005;84(5):1529-1532.

10. Nicole EK, Vanessa NW, Claudio AB, David WS, Lawrence LE, John CN.In vitro fertilization outcomes in patients experiencing a premature rise in luteinizing hormone during a gonadotropinreleasing hormone antagonist cycle. Fertil Steril 2011;95(8):2592-2594.

11. Yoshimura Y, Wallach EE. Studies of mechanism(s) of mammalian ovulation. FertilSteril. 1987;47 (1): $22-34$.

12. Shoham Z, Jacobs HS, Insler V. Luteinizing hormone: its role, mechanism of action, and detrimental effects when hyper secreted during the follicular phase. Fertil Steril 1993;59(6):1153-1156.
13. Stanger JD, Yovich JL. Reduced in vitro fertilization of human oocytes from patients with raised luteinizing hormone concentrations during the follicular phase. $\mathrm{Br} \mathrm{J}$ Obstet Gynaecol1985;92:385-393.

14. Howles CM, Macnamee MC, Edwards RG, Goswamy R, Steptoe PC. Effect of high tonic concentrations of luteinising hormone on outcome on in vitrofertilisation. Lancet. 1986;2(8505): $521-522$.

15. Homburg R, Armar NA, Eshel A, Adams J, Jacobs HS. Influence of serum luteinising hormone concentrations on ovulation, conception, and early pregnancy loss in polycystic ovary syndrome. BMJ. 1988;297(6655):1024-1026.

16. Regan L, Owen EJ, Jacobs HS. Hypersecretion of luteinising hormone, infertility and miscarriage. Lancet 1990;336(8724):1141-1144. 